\title{
Accounting
}

\section{The effect of non-performing loans on profitability of commercial banks: Case of Vietnam}

\author{
Hoai Linh Do ${ }^{a^{*}}$, Thanh Xuan Ngo and Quoc Anh Phunga
}

\begin{tabular}{l}
${ }^{a}$ National Economics University, V \\
\hline C H R O N I C L E \\
\hline Article history: \\
Received November 262019 \\
Received in revised format \\
November 282019 \\
Accepted January 22020 \\
Available online \\
January 5 2020 \\
\hline Keywords: \\
Non-performing loans \\
Profitability \\
Commercial bank
\end{tabular}

\section{A B S T R A C T}

Profit always be the top priority of banking operation over the years. Commercial banks maximize the net interest margin by charging more interests to the borrowers and offering lower interests to the depositors. Their aggressive lending strategies can sometimes result in credit risk, moral hazard and non-performing loans. Some studies found that non-performing loans have negative impact on the bank's profitability; some argued otherwise. This paper aims at investigating the impact of non-performing loans on the ability to make profit of Vietnamese commercial banks in the period of 2008 to 2017 and draws a conclusion as well as recommendations to mitigate the risk.

\section{Introduction}

(C) 2020 by the authors; licensee Growing Science, Canada

Vietnamese banking sector includes of 42 licensed commercial banks and the total assets of up to 9.25 billion VND (SBV, 2017). Such tremendous amount of assets and so many institutions provide Vietnam with a very good mobilization in financial resources for the growth by spreading credits to local and foreign businesses. Bank, like other business, is considered successful mostly based on the profit and the quality of assets. Some main criteria of a business performance are often related to the asset quality, the progress rate or price behavior. However, these elements only test the desirability of the profit system. Within the system itself, profit is the most crucial test of an individual's performance (Berger \& Humphrey, 1992). Profit is considered as a motivating force that keeps a business running. Profit can reflect a firm's progress and, at the same time, test the efficiency of such progress (Vinh, 2017; Krakah \& Ameyaw, 2010; Karim et al., 2017). Economists even consider profit to be the magic eye that mirrors the whole picture of a bank, including all aspects of the entire operation. Profit can play a different role to each part of the system. For instance, to a manager, profit is an efficiency test and a control measurement; to a creditor, it could be the safety boundary; to the owners, it is the evaluation of worth reflecting their investment; to the employees, profit is a source of marginal benefits; to the customers, it could show a sign to demand for higher product quality and price cuts; to an enterprise, it contributes as a less cumbersome flow of finance for stability and growth; and lastly to a country, profit reflects the whole economic progress. The traditional way of bank for making profit has long been lending and this has become the heart of banking industry and generates the biggest amount of operating income. However, banks can be exposed to many levels of risk as a result of excessive loans. Though there are some creations of adequate provisions to ease these risks, when the non-reforming loans (NPLs) ratio is high, risk becomes weak.

\footnotetext{
* Corresponding author.

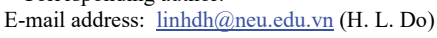


Vietnam, like most countries in the world, has suffered problems relating to banks in the past. Quang (2015) summarized such tragic events of banking. Most of the incidents are somewhat as a result of the 2008 crisis and spread from the period of 2009 to 2013. Some determinants in those crises are considered in high NPLs or high borrowings from the State Bank of Vietnam (SBV). The fact is, since 2008 crisis, the NPLs ratio in Vietnam has been rising and become unpredictable. The SBV (2017) has confirmed that the NPLs ratio is beyond expected and is up to $8.86 \%$. In the first half of 2018 , the rate of NPLs has decreased down to $0.73 \%-4.07 \%$ and the profitability of many banks have grown a lot since then. On some cases, studies confirmed the inverse relationship between NPLs and profitability such as studies of Wheelock and Wilson (1994) or Berger and Humphrey (1992), which stated that banks with high NPLs ratio and low efficiency have tendency to fail. On other cases, some failed to confirm such relationship between NPLs and profitability such as studies of Kwan and Eisenbeis (1996) or Karim et al. (2010). Therefore, in this research, investigation on the effect of non- performing loans on profitability of commercial banks in Vietnam will be conducted to clarify the relationship between NPLs and profitability. Therefore, the authors will promote some solutions to mitigate the risk.

\section{Literature review}

\subsection{Concept of profitability}

For many years, profitability used to be considered as the top priority of banking operations. Even in recent years, it has received significant amount of attention by experts, which results in a huge pool of literature that examined how important the role of resources management is in determining profitability. Profit could be defined as the difference between total revenues and total costs over a period of time. Other than a brief definition, there is a universal agreement with what profit can be defined as. The agreement announces profit as a residue or a surplus of price over the costs of production. However, the definition above has not been proven to be much useful, because it is lacking to show how profits arise. Overall, the term profit is still open to controversy over the meaning of terms that are included in the definition, namely; price, costs, expenses and so on. Profit must necessarily be a remaining sum on the income statement. The net profit is identified as a sum over and above the expenses of the business in the first place, which includes contractual payments. In the case of businesses, no one contracts to pay the residual sum or the net profit to the entrepreneur, so the profit is given under a form of payment by a factor of production namely the organizer. The organizers take care of the land, labor and also capital; thus, they produce goods and sell them while unwillingly bearing the undesirable and uninsurable risk. In the case where they successfully manage to keep the risk under control, they will receive the reward of profit. The word "profit" contains a different meaning for various parties like businessmen, tax collectors, accountants, bankers, economists, etc. With the diverse identification of such, the word is often used in a loose sense that covers up the significance and twists the basis of its discussion. The definition of profit in economics is considered sufficient, as in accounting practice (Norris, 1945). It has always been regarded as the difference between the cost that one must take for producing and selling goods and the return by selling such goods and services over a unit of time. This way of defining profit has been proven to be objective and quite precise.

Profitability is a relative measure which refers to the ability of an entity to earn profit (Tulsian, 2014). The profitability of such entity is the final result of numerous policies, along with many decisions made by that entity itself. The profitability is well considered as the primary measurement which reflects the overall success of a business and shows how effectively the business has used its resources. The term "profitability" is a compound word, composed from the two words: "profit" and "ability". Each word has its own meaning which contributes to the main one. The word "ability" refers to the earning power, or in other circumstances, the operating performance of the concerned investment. The definition of profitability can be extracted from the meaning of the composing words, which is defined as the ability of a gaining the return from a given investment. In other words, the profitability can also be defined as the capability of the entity to generate revenues that excess the costs. Thus, the increase in profit does not necessarily conclude that the profitability of the certain entity will increase. One significant feature of the profitability concept is its varying nature. The profitability is not a constant and unshakeable phenomenon that remains unchanged by its determinants; instead, it is a varying one. Since the change in one determinant can lead to the change in profitability itself, some even consider it as a reasonable to pair profitability and weather in comparison. The comparison can be strengthened by the following three arguments:

First, profitability's varying state is much like that of the weather of a day. The weather can most likely change depending on the change in temperature, humidity and other factors that relevant to it. The same goes for profitability when it will most likely change with a change in its determinants.

Secondly, the process of studying weather on the particular day allows us to make a possible forecast of the weather on the next day. Profitability and weather are similar, because analytical research on the profitability of a particular firm can also give us the forecast. In other words, the study on current trend of a certain profitability can result in the prediction of the possible trend of profitability in the future. 
Finally, not only can the results of the studies be concluded in a similar way, the processes of the studies are also very similar. For instance, the research on the determinants of profitability by a financial analyst can be familiar with the study of weather factors conducted by a meteorologist.

\subsection{Bank profitability indicators}

Many indicators can be used to measure the profitability of a bank and the superiority. According to Goudreau and Whitehead (1989) and Uchendu (1995), among indicators, return on assets (ROA), return on equity (ROE) and net interest margin (NIM) are the three best indicators. Accordingly, measurement of profitability by ROE was used by Hancock (1989); and by NIM was conducted by Odufulu (1994).

\section{Return on Assets (ROA)}

The return on assets is considered as an important indicator of profitability of an entity relative to its total assets. The ROA gives analysts the idea of how efficient the management is at spending its assets to harvest earnings. The ratio is displayed as a percentage and calculated by dividing the annual earnings or, in other word, net income by the total assets. The formula for ROA is as below:

$$
\text { RoA }=\frac{\text { Net income }}{\text { Total Assets }}
$$

ROA shows the earnings generated from the invested assets. For a public company, ROA will greatly depend on the industry and can vary significantly. For this reason, the best way of using ROA for a comparative measurement is to compare with the previous ROA of the same or similar company. Both debt and equity comprise the company's assets and both types of assets are used to fund the company's operations. By looking at the ROA ratio, investors can have the idea of whether the company is effectively converting its assets into net income or not. Higher ROA means better performance because it shows that the company is earning more on less spending. ROA is the most often used indicator of profitability, which appeared in various studies like that of Trujillo-Ponce (2013).

\section{Return on Equity (ROE)}

Return on equity is much similar to the ROA and is widely used in many studies to represent the profitability alone or with ROA and NIM. It is the amount of return or net income in the form of percentage of the shareholder's equity. The ROE too can be considered as an indicator of profitability because it reveals how much profit the company earns with the amount of money that shareholders have invested. ROE is represented in percentage and calculated with the formula:

$$
R o E=\frac{\text { Net income }}{\text { Shareholder's Equity }} .
$$

The net income is included for the whole fiscal year (before dividends were distributed to the stock holder but after preferred stock) and preferred shares are not included in shareholder's equity. The ROE is most useful when comparing profitability of two or more firms within the same industry is needed. ROE also provides a signal of financial success because it indicates whether the entity is gaining profit without pouring new equity capital into the business. On the other hand, ROE also acts as a growth rate speed limit, which is used by money managers to predict the growth potential.

\section{Net Interest Margin (NIM)}

The net interest margin, or NIM, among the factors that measure the bank efficiency, is considered as one of the most important ones. It is an intermediary that contributes to the process of collecting savings and providing loans. The NIM is calculated by the following formula:

$$
N I M=\frac{\text { Net interest income }}{\text { Total Assets }} .
$$

Several studies have shown that the high NIM is a barrier for investing in an economy and may decrease the growth diversity (Obeid \& Adeinat, 2017). A high NIM can be the result of the low interest rate on the deposit and high interest on the loans, which lower the saving desire and strengthen the cost of borrowing for potential borrower, leading to a decreased investment. However, a low NIM cannot be identified as a good indicator. Due to this complication, the NIM rate appeared in less studies compared with the other two profitability indicators. Nonetheless, NIM is still proven to be an effective indicator for profitability in research papers by Martinho et al. (2017) and Obeid and Adeinat (2018).

\subsection{Non-performing loans (NPLs)}

\section{Definition of Non-performing loans}

Non-performing loans (NPLs) is also known by non-performing assets (NPAs). This kind of loan refers to those that were unable to be repaid and its balance remains the same in a long period. Usually, when a payment is late for 90 days, it will be classified 
as non-performing. NPLs reflect some aspect of the bank's performance. The level of the NPLs can be considered as the best indicator for the health of the banking industry (Symss et al., 2018).

\section{Non-performing loans measuring method}

There are numerous ways to measure the non-performing loans (NPLs). Among them, quantitative and qualitative methods are mostly used. If the bank can calculate the probability of default, it is the quantitative method. On the other hand, using qualitative method can only help estimating the number. In the quantitative method, according to Basel II, commercial banks are allowed to use the method called Foundation Internal Rating Based (F-IRB) to evaluate and calculate the credit risks. The F-IRB method is a fresh seed in Basel II, providing banks with the calculation of risks. This method is suitable with banks of various sizes and based on different ranking of risks. The literature of the F-IRB is based on a stimulation model applying on credit risks, in which, the probability of customer's default is evaluated based on the difference between value of collateral assets and the face value of the loan. The value of an asset is varying over time, affected by random factors such as the change in market trend or the policy. The probability of default will incur when the value the collateral assets is lower than the face value of such loan. To measure NPL, banks have to follow two main parts of the deal:

The first part is to identify the value of the risky assets. Banks must categorize the customers into groups like: firms, government, banks, individuals and so on. Next is to identify the risks components, including:

- Probability of default (PD): measuring the probability of credit risk in a period of time (usually one year).

- Loss given default (LGD): the loss that occurs in the case customer does default, which is described as a percentage over the face value of the loan. Banks must estimate this LGD for the amount they have to claim from each individual, enterprise and other banks.

- Exposure at default (EAD): the total amount of debt at the time that customers can no longer repay.

- Effective maturity (M): the maturity, which is set on 2.5 years according to the basic IRB, cannot exceed 5 years.

The F-IRB method required that the LGD rate set for these claims from these individuals must be at $45 \%$. Similarly, the standardized approach of banks can record the risk mitigation impact of collateral assets by adjusting the LGD or EAD risk reduction value. However, to avoid duplication, the adjustment of risk value is only performed once, only with LGD or only with EAD.

The second step is to adjust the equity value based on the difference between the total expected loss value (EL) and the total credit risk reserve. In order to determine the expected loss value, the bank must accumulate the expected loss value of all loans which belong to different risk groups; (ii) determine the total value of credit risk provision by the total of all types of provisions (including specific provisions, general provisions for national risks, general provisions for loans and receivables); the values of specific provisions for equity contributions and securitization securities are not included in the provision for credit losses; (iii) compare the total EL value and total credit risk provision value and make direct adjustment to the difference in equity value of these two values. The F-IRB method will be based on the unexpected and expected losses. The risk coefficient function is used as a basis for calculating the necessary capital needs for undesired losses (UL). The anticipated damages before EL will be considered separately. In the F-IRB method, the required reliability is $99.9 \%$, meaning that $0.1 \%$ of the bank's own equity probability will not be sufficient to offset the unexpected loss and this time banks will fall into insolvency.

In addition to the method based on basic internal rakings, the Basel II Treaty also allows banks to apply methods based on Advanced Internal Ratings Based (A-IRB) to measure credit risk use. In the A-IRB method, the estimation of LGDs can reflect the effectiveness of the risk mitigation impact of guarantee activity and derivative credit products by adjusting PD or LGD. LGD must be calculated according to the percentage of losses due to default against EAD. Thus, the Basel Committee has allowed banks to have two choices: one is the basic IRB method and the other is the advanced IRB method.

If basic IRB is used, banks only estimate probability of default (PD) themselves and rely on supervisor's estimations for other risk factors. If an advanced IRB is used, the bank will have to make estimations for all risk factors including PD, LGD and $\mathrm{EAD}$, and calculate the $\mathrm{M}$ variables themselves, and must follow minimum standards. For both basic and advanced methods, banks must always use the risk coefficient function according to the specific provisions of the treaty. Although the calculation of minimum capital demand is only to compensate for the unexpected losses, banks must also handle it to compensate for the expected losses based on the same basis, including price policy, redundancy and complete disposal.

\subsection{Theoretical Review}

\section{Asymmetric Information Theory}

The Asymmetric Information Theory is a famous theory related to the situation where faulty knowledge occurs, in specific, it is likely to happen when two or more parties have different information over each other. One stands out example of asymmetric information in financial markets is when the borrower has a better information of his financial state than the lender. Pagano and 
Jappelli (1993) proved that information sharing can improve bank's information on the credit applicants and shrink the probability of adverse selection. The theory indicated that it is hard to differentiate between a bad and a good borrower; this may affect the lending behavior and can result in adverse selection and moral hazards problems. Auronen (2003) explained that in the market, the party that holds a better information can negotiate a more optimal term in the transaction. Therefore, the party with the less specific information stands in the position to make an either right or wrong decision in terms of the transaction. This creation of moral hazards and adverse selections can lead to an increase in the NPLs (Bofondi \& Gobbi, 2003). In other cases where bank's managers have more knowledge on how the NPLs affect the profitability than the stakeholders, the bank is more likely to fail in NPLs disclosure and need to use provision for loan losses.

\section{Modern Portfolio Theory}

The Modern Portfolio Theory (MPT) is the most powerful theory in economics that deals with finance and investment by Markowitz (1952). Being known as the phrase "not putting all your eggs in one basket", the theory evaluates the benefits of diversification. It is a theory about investment which takes effort to explain how investors could minimize the risk and maximize the profit through investing in various assets. According to Atemkeng and Nzongang (2006), the theory has the closest approach and plays an important role in studies about banking performance. It implies that the bank managements are responsible for the diversification of portfolio and desired portfolio composition of that bank. Thus, the ability to create maximum profits largely depends on the feasible set of assets and liabilities and the unit costs incurred by the bank for producing each component of assets (Atemkeng \& Nzongang, 2006). As consequences, commercial banks should consider reducing or minimizing the default risk form credit takers in loans repayments which cause the rise in NPLs, affecting the profitability. Furthermore, the concept of revenue diversifications, following the concept of MPT, stated that not only bank but also individuals can diversify their own portfolio to decrease the firm-specific risk. As summary, Modern Portfolio Theory encourages the activities of diversification which provides a more stable income and the ability to leverage managerial efficiency across products and for the case of commercial banks, reduces NPLs and increases return on assets (ROA). The Asymmetric Information Theory recommends that transparency when making a loan is very important, otherwise both the bank and the customers will suffer from unexpected outcome, especially the banks which could end up with a high rate of NPLs.

\subsection{Effects of non-performing loans on bank profitability}

Non-performing loans and profitability relationship has been in the center of banking studies due to its potential for regulatory policies. Looking through some researches that was previously made, it can be concluded that the NPLs may have a negative impact on the profitability, or in other words, making banks inefficient (Demirgüç-Kunt \& Huizinga, 1999). Researches on bank profitability started to consider the asset quality, which includes non-performing assets (NPAs). Another research by Athanasoglou et al. (2008) showed that loans with such low asset quality will earn less profit. This again confirms the negative relationship between bad debt and the ability to make profit of banks. The hypothesis proposed by Berger and DeYoung (1997) also supports the above findings stating that the better the bank at managing their credit risk, the more efficient the bank is. Banker et al. (2010) used a panel data set over the period of 1995-2005 for 14 Korean commercial banks to conduct the research. The outcome implied that the NPLs rate put a negative impact on the bank productivity. Banker et al. (2010) also stated in the same research that when the importance of NPLs is unawarded, banks could experience a disadvantage in the lending behavior. In addition, if the NPLs gets out of hand, this will have bad effect on the profitability. A research by Andries (2011) recommended a solution that NPLs should be limited to enhance efficiency of banks. Once again, the negative relationship of NPLs and profitability was proven to be statistically significant when it was examined between 2004 and 2009 in Central and Eastern European banking sector. The same result was produced when Trujillo-Ponce (2013) evaluated the determinants of productivity among Spanish commercial banks in the period of 10 year starting from 1999. With the sample of 89 banks and 697 observations, the paper proves that NPLs had a negative impact on both ROA and ROE at a certain level of significant. Other researcher used the data set of 34 Vietnamese commercial banks from 2005 to 2015 and applied the generalized method of moments technique (GMM) for dynamic panels to determine the impact of NPLs on bank's performance and how it affects the lending behavior. Throughout the research, some evidences were found indicating that the NPLs and the commercial bank profitability, as well as lending behavior, had a statistically significant negative relationship among each other. Following the results, he again confirmed that higher level of NPLs found to be harmful and can reduce bank's lending offer. In another paper, Quang (2015) tried to identify the determinants of banking crisis in Vietnam. He explained how banking crisis was associated with the bank performance. Using data sample from 30 commercial banks from the period of 2005 to 2013 and multivariate logit model, he concluded that the banking crisis, most of the time, occurs when there is a high level of NPLs and high borrowings from SBV. He also studied about the alerting NPLs ratio threshold. By applying the noise-signal method, his conclusion was that the optimal ratio in Vietnam case should be 5.5\%. NPLs on total outstanding loans ratio (NPLs ratio) is the most interesting independent variable in the model. NPLs ratio represents the quality of the bank's debt and the level of credit risk that the bank has to bear in the present and in the future. Therefore, a hypothesis was given to the case of Vietnam:

The NPLs ratio has a statistically significant and negative relationship with bank profitability. 


\section{Methodology and Data}

\subsection{Research design}

The study used descriptive survey, which is a design that involves establishing what is happening as far as a particular variable is concerned. The study covered the time series between 2008 and 2017, which is the time period where there is the global financial crisis and after Vietnam has been more open with the international financial market and suffer some damage from the crisis. Furthermore, during this time, the non-performing loan was reported to be constantly high and unresolved until 2017.

Population: The principle of observation pool required the minimum observation to be five times the number of variables. The number of variables in each model is set at maximum of 10 . Therefore, one must have at least 50 observations to conduct a practical research. With the panel data of 15 Vietnamese commercial banks from the period of 2008 to 2017, the research will be conducted with 150 observations, which suitability meets the requirements. Cross units have the same number of observations over times so this data is balanced panel data.

Data collecting and processing method: Secondary data on variables in the research model are collected from reliable sources. Specifically, the data of annual growth rate of gross domestic product (GGDP) is taken from the Vietnam section of World Bank data from 2008 to 2017. Other data for calculating the variables such as: the profitability (ROA), the loans to deposits ratio (LDR), the non-performing loans ratio (NPLs) and the bank sizes (BANKSIZE) are all collected from the annual report of 15 Vietnamese commercial banks from 2008 to 2017.

\subsection{Research model}

Based on the theoretical relationship among variables and the previous regression model, a newly modified model was introduced by Gwahula and Mnyavanu (2018) to examine the relationship between NPL and ROA:

$$
R O A=\alpha+\beta_{1} N P L+\beta_{2} L D R+\beta_{3} C A R+\beta_{4} G G D P+e .
$$

In this paper, the capital adequacy ratio will not be used because the credit risk of the loans will not be considered. Instead, the bank size will be added to the model to test whether the amount of asset the bank processes will affect the profitability or not, since the total assets reflect the bank size. The variable BANKSIZE will be used and is equal to the logarithm of the total assets. the new model is as follow:

Table 1

$$
R O A=\alpha+\beta_{1} N P L+\beta_{2} L D R+\beta_{3} B A N K S I Z E+\beta_{4} G G D P+e .
$$

\begin{tabular}{|c|c|c|c|}
\hline Description & Name & Measurement & Expected Sign \\
\hline \multicolumn{4}{|l|}{ Dependent variable } \\
\hline Bank’s profitability & ROA & RoA $=\frac{\text { Net income }}{\text { Total Assets }}$ & \\
\hline \multicolumn{4}{|l|}{ Independent variable } \\
\hline Non-performing loan ratio & NPL & $\frac{\text { Non }- \text { performing loans }}{\text { Total loans }}$ & - \\
\hline Loans to deposits ratio & LDR & $\frac{\text { Total loans }}{\text { Total deposits }}$ & $+/-$ \\
\hline Size of bank & BANKSIZE & Logarithm (total assets) & - \\
\hline GDP growth rate & GGDP & $\frac{G D P_{t}-G D P_{t-1}}{G D P_{t-1}}$ & $+/-$ \\
\hline
\end{tabular}

Summary of variables in the research model

Non-performing loan ratio (NPLs): The NPLs ratio seriously threatens not only the financial stability of commercial banks but also the entire national monetary security system. When bad debts exceed the permitted limit (normally 5\%), commercial banks will lose a large amount of capital. This affects cash flows and banks will become illiquid, leading to possible bankruptcy, which will threaten the sustainable development of banks as well as its profitability. Bad debt results in reduced profits due to risks leading to many financial losses. Credit is the basic activity of the bank, bringing in the main revenue source. However, the revenue from credit activities entailed credit risks. The unrecovered debt (principal, interest and fees) causes the capital of commercial banks to diminish, leading to a difficulty in the ability to make profit. Studies from Demirgüç-Kunt and Huizinga (1999); Athanasoglou et al. (2008); Berger and DeYoung (1997) found a negative correlation between bad debt ratio and the profitability of commercial banks. When NPLs ratio increases, the bank profitability will be reduced.

Loans to deposits ratio (LDR): The bank makes most of its profit from the net interest margin (Towpek \& Borhan, 2006). The ratio of loans to deposits ratio is calculated by dividing the total loan amount to the total deposits. Abreu and Mendes (2002) 
announced that there was a statistically significant and positive relationship between loans to deposits ratio and bank profitability. The more loans that the bank can make, the higher revenues they may generate. Furthermore, the main source of funds for these loans are from the deposits, which are likely the cheapest source of fund. On the other hand, there are some study stated the opposite.

Bank size (BANKSIZE): Calculated by the total assets of the bank. The relationship between bank size and bank profitability has been studied in various countries but the result remains controversial. Studies by Redmond and Bohnsack (2007), convinced that the larger banks face more threats from information asymmetry. On the other hand, researches from Bourke and DeYoung (1997) showed opposite relationship between bank size and bank profitability, explaining that with the larger pool of capital, banks can make better investment and avoid bankruptcy cost.

GDP growth rate (GGDP): The annual growth of the GDP is calculated by taking the difference between GDP of current year and the year before and divide it by the GDP of the last year. The GGDP is a macroeconomic variable which receives many attentions from researchers. Investigation by Hefferman and $\mathrm{Fu}$ (2008) about banking in China showed a relationship between GDP growth and the bank's profitability.

\subsection{Research method}

In the first step, the descriptive statistical method is used for the preliminary analysis of the research sample in order to find maximum value, minimum value, mean value, variance and standard deviation. The data gathered from 15 Vietnamese commercial banks in the period of $2008-2017$ is panel data. Therefore, the authors will use regression models with panel data to perform tests. With the assumption that each entity has its own characteristics that may affect explanatory variables, fixed effects model (FEM) analyzes the relationship between NPLs and bank performance with explanatory variables. FEM controls and separates the influence of the individual characteristics (constant over time) from the explanatory variables so that we can estimate the net effects of the explanatory variables on the dependent variable. The estimation model used in this method takes the form of:

$$
Y_{i t}=C_{i}+B X_{i t}+u_{i t}
$$

where, $Y_{i t}$ is the dependent variable with $i$ represents the bank and $t$ is the time (year). $X_{i t}$ are independent variables, $C_{i}$ is the intercept for each observed entity, $B$ is the slope and $u_{i t}$ is the balance.

Fixed effects model has added index $i$ for $C$ blocking coefficient to differentiate the intercept of each different bank that may be different. This difference may be due to different characteristics of each bank or due to differences in management policies and operations of the bank. If the selected model happens to be self-correlated or the variance changes through the entity, feasible general least square (FGLS) will be used to overcome this phenomenon.

\section{Results and discussion}

\subsection{Descriptive statistics and correlation between variables}

Descriptive statistics: The desrciptive statistic results (Table 2) show that the commercial bank's profitability measured by ROA have the mean of $0.89 \%$ and the fluctuation of the remaining values around the mean value is 0.0056 . The highest level of profitability is $2.88 \%$ and the lowest is negative $1.34 \%$. The bank with the lowest level of profitability is Tien Phong Commercial Joint Stock Bank in 2011 with the ROA of $-1.34 \%$ and the bank with the highest level of profitability with ROA of $2.88 \%$ is Kien Long Commercial Joint Stock Bank in 2013.

\section{Table 2}

Descriptive statistic results

\begin{tabular}{lccccc}
\hline Variable & Observation & Mean & Standard deviation & Min & Max \\
\hline ROA & 150 & 0.0089664 & 0.0055867 & -0.01393 & 0.0288228 \\
NLP & 150 & 0.0211497 & 0.0140838 & 0.0883021 & 1.423795 \\
LDR & 150 & 0.8850906 & 0.1815059 & 0.2346416 & 0.06812 \\
GGDP & 150 & 0.060078 & 0.0052891 & 0.05247 & 7.79111 \\
BANKSIZE & 150 & 11.49618 & 1.289862 & Source: Author's calculation using Stata 14
\end{tabular}

The ratio of NPLs to total average debt of 15 commercial banks is $2.11 \%$, in which, the bank with the highest NPLs ratio was Saigon - Hanoi Joint Stock Commercial Bank in 2012 with the significantly high NPLs ratio of $8.83 \%$. The bank with the lowest NPLs rate of 0\% was Tien Phong Commercial Joint Stock Bank in 2008 and Vietnam Prosperity Commercial Joint Stock Bank in the same year of 2008. The mean of LDR of 15 commercial banks is $88.5 \%$, in which, the bank with the highest LDR of $142.23 \%$ was Ho Chi Minh Development Commercial Joint Stock Bank in 2008. The bank with the lowest LDR of 23.46\% was Tien Phong Commercial Joint Stock Bank in 2008. The bank size which is mesuared by total assets has the mean value of 11.49. The bank which has the smallest size with the value of 7.79 was Tien Phong Commercial Joint Stock Bank in 2008. On the other hand, the largest bank with the value of 13.99 was Joint Stock Commercial Bank for Investment and Development in 
2017. The average growth rate of GDP in the period of $2008-2017$ is $6 \%$, in which the highest growth rate is $6.812 \%$ achieved in 2017 the lowest GDP growth rate is $5.247 \%$ in 2012 .

Correlation results: The correlation between the variables in the model is shown through the correlation coefficient matrix in Table 3.

Table 3

Correlation coefficient matrix

\begin{tabular}{lcccc}
\hline Variable & ROA & NLP & LDR & GGDP \\
\hline ROA & 1.0000 & & & \\
NLP & -0.1748 & 1.000 & 1.0000 & \\
LDR & 0.1360 & 0.0069 & 0.0515 & \\
GGDP & -0.1742 & -0.2052 & 0.0616 & 0.0000 \\
BANKSIZE & -0.1147 & 0.0012 & & Source: Author's calculation using Stata 14
\end{tabular}

Correlation coefficient measures the degree of linear relationship between two variables regardless of the dependence of variables. Based on the regression results, the correlation coefficients of the independent variables are majorly lower than $60 \%$, which means that these independent variables have low correlations.

Multicollinearity test: Multicollinearity is the phenomenon where the independent variables in the research model have linear relationship. When the VIF index is greater than 5, there is a high degree of multicollinearity among variables. Results in Table 4 show VIF less than 5, which means there is no linearity among the independent variables. Therefore, these variables can be uses for regression analysis.

Table 4

Multicollinearity among independent variables

\begin{tabular}{llc}
\hline Variable & VIF & $1 /$ VIF \\
\hline GGDP & 1.12 & 0.890052 \\
BANKSIZE & 1.08 & 0.928351 \\
NLP & 1.05 & 0.954566 \\
LDR & 1.01 & 0.994613 \\
\hline Mean VIF & 1.06 & Source: Author's calculation using Stata 14
\end{tabular}

\subsection{Regression results}

Using Stata 14 software with panel data of 150 observations $(n=150)$ from 15 subjected banks across the period from 2008 to 2017, the results from fixed and random effects model are shown in Table 5 as follows:

Table 5

Estimated results using the Fixed and Random effects model

\begin{tabular}{|c|c|c|c|c|c|}
\hline & $F E M$ & $R E M$ & & FEM & $R E M$ \\
\hline Variable & ROA & ROA & Variable & ROA & $\mathrm{ROA}$ \\
\hline \multirow{2}{*}{$N P L$} & -0.0458 & $-0.0655^{*}$ & \multirow{2}{*}{$B A N K S I Z E$} & $-0.00186 * *$ & -0.000853 \\
\hline & $(-1.44)$ & $(-2.13)$ & & $(-2.63)$ & $(-1.72)$ \\
\hline \multirow{2}{*}{$L D R$} & $0.00791 * *$ & $0.00675 * *$ & \multirow{2}{*}{ _cons } & $0.0307 * * *$ & $0.0249 * * *$ \\
\hline & -2.93 & -2.66 & & -4.22 & -3.94 \\
\hline \multirow{2}{*}{$G G D P$} & -0.106 & $-0.178 *$ & \multirow[t]{2}{*}{$N$} & \multirow[t]{2}{*}{150} & \multirow[t]{2}{*}{150} \\
\hline & $(-1.18)$ & $(-2.14)$ & & & \\
\hline
\end{tabular}

Source: Author's calculation using Stata 14

According to Table 5, the estimation of the fixed effects model shows that only the loans to deposits (LDR) and the size of bank (BANKSIZE) have statistically significant effect on the profitability (ROA) of the commercial banks at 5\% significant. The regression coefficient of variable LDR and BANKSIZE when estimating by the fixed effects model is consistent with the sign's expectation. When using the random effects model, the non-performing loans ratio (NPLs), the loans to deposits (LDR), the annual growth rate of GDP (GGDP) have statistically significant effects on the profitability (ROA) of the commercial banks at $5 \%$ significant. Furthermore, the regression coefficient of these variables when using the random effects model are all consistent with the expectation of the signs. The Hausman test was conducted to identify the more suitable model between fixed and random effect model, the result yields Chi-Square $=6.32$ with Prob $>$ Chi-Square $=0.1765$. The null hypothesis assumes that the estimations obtained from the two methods are undifferentiated. If the null hypothesis is rejected, FEM is a more suitable model. According to the test result from Table 6, the p-value is 0.1765 and is higher than the significant level of 5\%. Therefore, the Random effects model is the most appropriate model. Furthermore, the verification of variance changes through entities in 
case the random effects model is used is performed through Wald calibration, the test result yields Chi-Square $=1553.13(0.000)$. The null hypothesis is rejected, meaning that the variance through entities is changed. Next, Wooldridge test is used to test the autocorrelation in panel data. The test results yield $\mathrm{F}(1,14)=54.833(0.000)$. In conclusion, the research model which was estimated by using random effects model has the phenomenon of changing deviation and autocorrelation. To deal with the problem, the research model is estimated again, this time using the feasible general least square (FGLS) method. The result is as follow:

\section{Table 6}

Feasible General Least Square method result

\begin{tabular}{lccccc}
\hline ROA & Coef. & Std. Err. & $\mathrm{z}$ & $\mathrm{P}>|\mathrm{z}|$ & 0.006 \\
\hline NLP & -0.086038 & 0.0313899 & -2.76 & -0.1482269 & -0.0251808 \\
LDR & 0.0046976 & 0.0023861 & 1.97 & 0.049 & 0.0000209 \\
GGDP & -0.2206235 & 0.08651 & -2.55 & -0.011 & -0.3902799 \\
BANKSIZE & -0.0003036 & 0.0003475 & -0.87 & -0.050971 & 0.382 \\
cons & 0.0233874 & 0.0060569 & 3.86 & 0.000 & 0.0009848 \\
\hline
\end{tabular}

According to the result frog Table 9, the non-performing loans ratio (NPLs), the loans to deposits (LDR), the annual growth rate of GDP (GGDP) have statistically significant effect on the profitability (ROA) of the commercial banks at $5 \%$ significant. This proves that the non-performing loans ratio (NPLs), the loans to deposits (LDR), the annual growth rate of GDP (GGDP) have statistically significant effect on the bank profitability (ROA). The bank size (BANKSIZE) is not statistically significant, meaning that it has no impact on the bank profitability. This could be due to the fact that the amount of assets the bank process does not necessary explain the bank's profitability. The result shown above proves that the original Hypothesis of this research is not rejected.

\subsection{Further discussion}

Non-performing loan ratio (NPLs): Regression coefficients of NPL $=-0.0867$, which is negative and statistically significant, indicating the negative impact of bad debt ratio over total debt to ROA. When this ratio increases, the NPLs decrease and the bank profitability will increase. This result is consistent with the hypothesis of the research model. This means that when the rate of NPLs increases, Vietnamese commercial banks' ability to make profit will be reduced. This is also consistent with other researches of other countries from Banker et al. (2010), Andries, (2011) and Trujillo-Ponce (2013).

The NPLs ratio of not only Vietnam but also the world as a whole has been edging up steadily after the financial crisis in 20072009. The NPLs rate could be problematic to the bank, resulting in a sluggish recovery. The delay in debt repayment often prevents future credit approvals, leading to a second round of debt default. This causes borrower to fall in to a hash situation and could stack up the NPLs rate of the bank. In Vietnam for instance, the National Joint Stock Commercial Bank (NVB) pushed its NPLs rate from $2.26 \%$ in 2011 to $5.65 \%$ in 2012, and continued to reach $6.68 \%$ in 2013 . This caused the NVB to have almost no profit in the following years. Another problem is that the high NPLs rate requires banks to have larger loan loss provisions, which limits the amount of loans that can be offered by banks. Research result shows that the LDR is positively related to the profitability, therefore, limiting the resources for lending will affect profitability. Big banks such as the Joint Stock Commercial Bank for Investment and Development of Vietnam (BIDV) - one of the biggest commercial banks in the sector, also suffers from this. Even though the loan offers increase by thousands of trillion VND each year, the bank's ROA only stays under 1\% and showing signs of decreasing in recent years. This means that the bank is only making profit due to its large pool of capitals, but the real profitability is really low.

The result also suggests that instead of focusing on lending, Vietnamese commercial banks should pay more attention on screening and monitoring the loan default risk in order to maximize the profit-making ability.

Loans to deposits ratio (LRD): Regression coefficients of $L R D=0.0469$, which is positive and statistically significant, proving that with the higher loans to deposits ratio, the better the profitability of Vietnamese commercial banks, which is consistent with the studies result from Abreu and Mendes (2002). The main way to gain profit of a bank is to increase the lending rate and lower deposit rate to customers. In Vietnam, most commercial banks make use of this and therefore, maximize the amount of loan they can offer. Vietnamese commercial banks do not face with a lot of liquidity risk as long as the banks keep the loans below the deposit amount. As can be seen from Fig. 1, most listed banks kept the LDR less than 100\%, when the ratio goes beyond that bar then banks face the real risk. Some banks are still willing to take the risk due to the high reward, particularly the Petrolimex Commercial Joint Stock Bank during the period of 2008 to 2013. Some banks only keep the LDR below 100\% and increase it slowly to gain more profit and to avoid a shock in the liquidity pool. For instance, Ho Chi Minh Development Commercial Joint Stock Bank increased its LDR slowly from 63,99\% in 2014 to $86,69 \%$ in 2016. Kien Long Joint Stock Commercial Bank during 2011 to 2017 dropped its LDR from 103.26\% to 80.76\% in 2015. As the result, its ROA decreased from $2.21 \%$ to $0.65 \%$. After this, the bank pushed back its LDR rate and the ROA slowly recovered. 


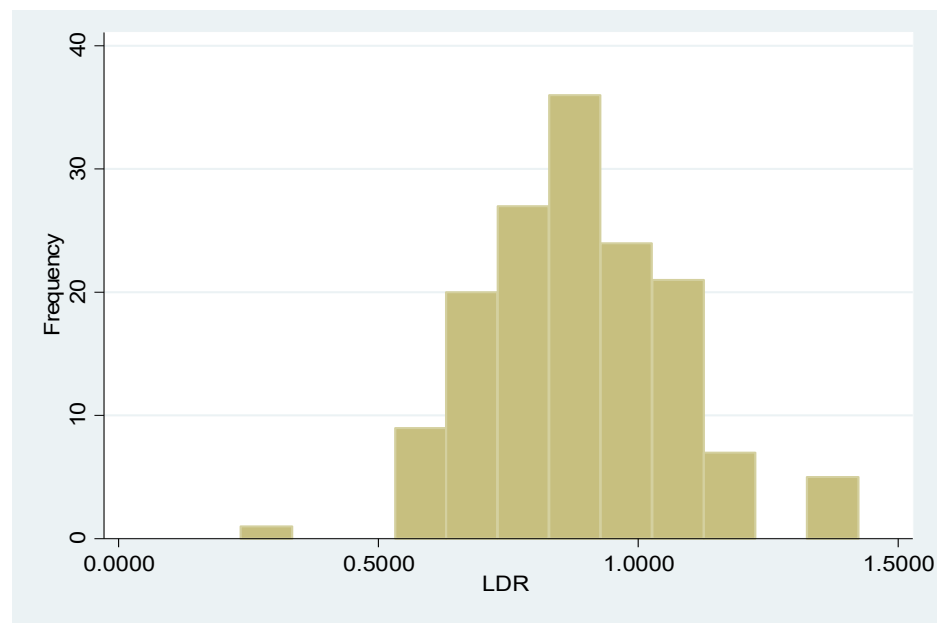

Fig. 1. Histogram of LDR frequency

Annual GDP growth rate (GGDP): Regression coefficients of GGDP $=-0.0867$ is statistically significant. This means that the GDP growth of Vietnam has negative impact on the bank's performance. Therefore, it can be concluded that with in the growing economy, the banks of Vietnam are more likely to perform worse.

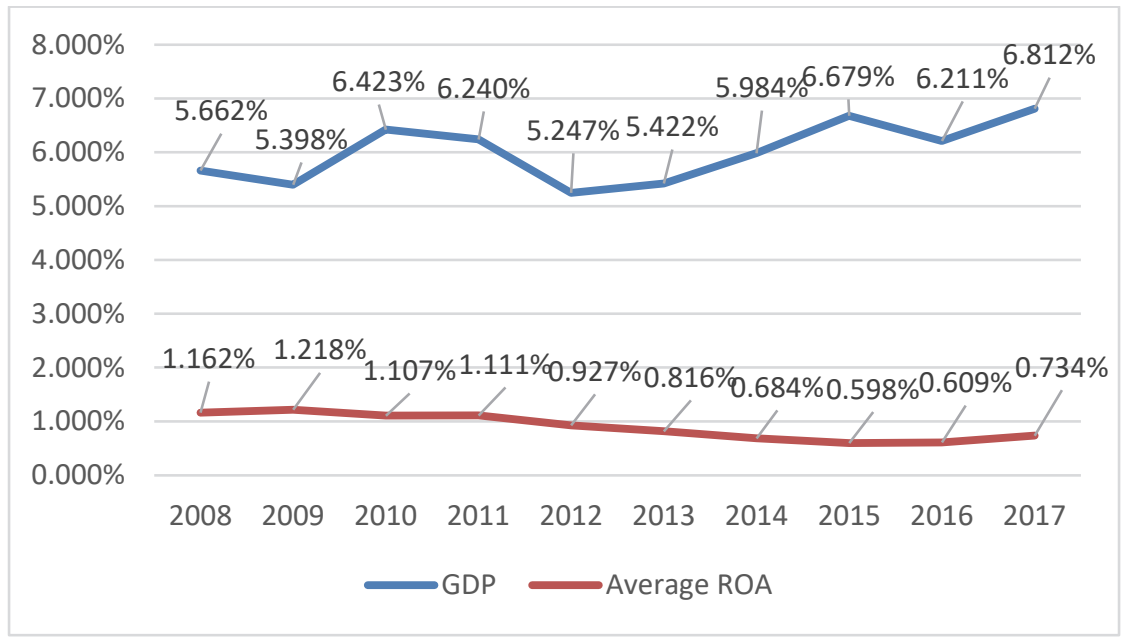

Fig. 2. GDP growth and average bank's ROA from 2008 to 2017

Source: Author's compilation

The high GDP growth indicates that the economic is stable and well developing. With the developing economy, demand for credit would rise as the needs to expand investment and productivity also rise. Such economies will let banks offer deals more confidently, at the same, time trigger the liquidity risk. If the lending activities are made, so are the default risk and the profitability. The moral hazard can cause banks to make riskier trades; risk management can be loosened. As can be seen in Fig. 2 , at the beginning of the crisis that happened in 2008, the GDP fell from 5.662\% to 5.398\% in 2009. At the same time the ROA of commercial banks slightly increased from $1.16 \%$ to $1.21 \%$ in 2009 . This could come from the demand for fund during the downfall of the economic; risky assets are retreated from commercial banks and more secure loans were made. The same pattern applied up to 2017. The period from 2012 to 2015 was when Vietnam's economy has recovered and begin to develop again, which is shown by the rapid increase in GDP from $5.247 \%$ in 2012 to $6.68 \%$ in 2015 and followed by the fall in average ROA of commercial banks.

\section{Conclusion and recommendation}

On the basis of inheriting the results of previous studies, the author uses the fixed and random effects model, as well as the feasible general least square method to construct the test with panel data. The test results have shown that when the rate of nonperforming loans increases, the bank's ROA will decrease, meaning that the bank profitability will be lowered. Furthermore, the research results have pointed out that in the case of Vietnam, the loans to deposits rate and the growth of GDP both have an 
impact on the bank's performance; while the bank size does not matter. Therefore, the authors suggest the following actions in order to prevent the impact of NPLs on bank's profitability:

Raising equity: Raising equity contributes to the ability of a bank responding to liquidity crisis and to cover for the bad debt, which is what the Modern Portfolio Theory recommended. Improving financial capacity such as capital and asset quality will provide the bank with back up for the unrecovered loans. However, this action needs to be proceeded with caution to avoid further volatility. In order to increase equity, banks need to develop a balanced policy in the distribution of profit for dividend payments and retain earnings. Banks need to retain some profits in addition to shareholders' equity to increase the scale of capital for future investment. Increasing equity often leads to dilution of the shareholdings. Therefore, bank owners need to accept this situation in order to expand pool of shareholders, thereby increasing equity to reduce the risk and increase stability. In addition, diluting the shareholding rate and limiting the concentration of large capital ownership in a small group of shareholders also promote the development of corporate governance, avoiding bank manipulation and acquisition by dominating group of shareholders. This unfortunate circumstance can cause great losses to other shareholders and distort the financial situation of banks.

Appropriate risk managing system: Commercial banks need to complete the Basel II credit risk management framework. A good credit risk management system must be placed in an appropriate risk environment. The risk management strategy should clearly identify the level of general risk and the level of credit risk tolerance to be the guideline for the risk management operation. The bank's credit risk strategy must be developed based on comprehensive assessments, thoroughly understanding of the bank's business situation and macroeconomic situation. The Board of Directors should be responsible for the final approval of the credit risk strategy. Credit risk management procedures must also be appropriate. In order to obtain a reasonable credit risk management process, the bank needs to establish reasonable credit risk criteria, appropriate authority hierarchy, and risk appetite of the bank. In addition, credit risk management policies coupled with credit growth, high-risk lending such as securities investments, and real estates need to be regularly reviewed to ensure the compliance with risk management strategies during each period. Furthermore, the system has to be carefully monitored and frequently evaluated to ensure the effectiveness and to avoid asymmetric information. This work is required to be carried out regularly by risk management departments and other independent monitoring departments.

\section{Acknowledgement}

This paper has been supported by National Economics University.

\section{References}

Abreu, M., \& Mendes, V. (2002). Commercial Bank Interest Margins and Profitability.

Andries, A. M. (2011). The determinants of bank efficiency and productivity growth in the Central and Eastern European banking systems. Eastern European Economics, 49(6), 38-59.

Athanasoglou, P. P., Brissimis, S. N., \& Delis, M. D. (2008). Bank-specific, industry-specific and macroeconomic determinants of bank profitability. Journal of international financial Markets, Institutions and Money, 18(2), 121-136.

Atemkeng, T., \& Nzongang, J. (2006). Market structure and profitability performance in the banking industry of CFA countries: The case of commercial banks in Cameroon. Journal of Sustainable Development in Africa, 8(2), 1-14.

Auronen, L. (2003, May). Asymmetric information: theory and applications. In Seminar of Strategy and International Business as Helsinki University of Technology.

Banker, R. D., Chang, H., \& Lee, S. Y. (2010). Differential impact of Korean banking system reforms on bank productivity. Journal of Banking \& Finance, 34(7), 1450-1460.

Berger, A. N., \& DeYoung, R. (1997). Problem loans and cost efficiency in commercial banks. Journal of Banking \& Finance, 21(6), 849-870.

Berger, A. N., \& Humphrey, D. B. (1992). Measurement and efficiency issues in commercial banking. In Output measurement in the service sectors (pp. 245-300). University of Chicago Press.

Bofondi, M., \& Gobbi, G. (2004). Bad loans and entry into local credit markets (Vol. 509). Banca d'Italia.

Demirgüç-Kunt, A., \& Huizinga, H. (1999). Determinants of commercial bank interest margins and profitability: some international evidence. The World Bank Economic Review, 13(2), 379-408.

Goudreau, R. E., \& Whitehead, D. D. (1989). FYI Commercial Bank Profitability: Improved In 1988. Economic Review-Federal Reserve Bank of Atlanta, 74(4), 34.

Gwahula, R., \& Mnyavanu, W. (2018). Determinants of dividend payout of Commercial Banks Listed at Dar Es Salaam Stock Exchange (DSE). Account and Financial Management Journal, 3(06), 1571-1580.

Hancock, D. (1989). Bank profitability, deregulation, and the production of financial services (No. 89-16).

Hefferman, S., \& Fu, M. (2008). The Determinants of Bank-Performance in China. Ema Working Paper Series No. 032008. 
Karim, M. Z. A., Chan, S. G., \& Hassan, S. (2010). Bank efficiency and non-performing loans: Evidence from Malaysia and Singapore. Prague Economic Papers, 2(1), 118-132.

Krakah, A. K., \& Ameyaw, A. (2010). Determinants of Bank's Profitability in Ghana. The Case of Merchant Bank Ghana Limited (MBG) and Ghana Commercial Bank (GCB), A master" s thesis in business administration.

Kwan, S. H., \& Eisenbeis, R. A. (1995). An analysis of inefficiencies in banking. Journal of Banking \& Finance, 19(3-4), 733734.

Markowitz, H. (1952). Portfolio selection. The Journal of Finance, 7(1), 77-91.

Martinho, R., Oliveria, J., \& Oliveria, V. (2017). Bank profitability and Macroeconomic factors. Financial stability papers, Banco de Portugal, Lisbon, August, ISSN, 2183-4059.

Norris, H. (1945). Profit: Accounting theory and economics. Economica, 12(47), 125-133.

Obeid, R., \& Adeinat, M. (2017). Determinants of net interest margin: An analytical study on the commercial banks operating in Jordan (2005-2015). International Journal of Economics and Financial Issues, 7(4), 515-525.

Odufulu, O. (1994). Monetary Policy and Banks' Profitability in Nigeria. First Bank of Nigeria Plc Bi-Annual Review.

Pagano, M., \& Jappelli, T. (1993). Information sharing in credit markets. The journal of finance, 48(5), $1693-1718$.

Quang, L. (2015). Determinants of banking crisis: The case of Vietnam. Journal of Science, 4, 64.

Redmond, W. J., \& Bohnsack, C. L. (2007). Bank size and profitability: One nation, one bank?. International Journal of Business Research, 7(1), 162-169.

Symss, J., Saradhi, V. R., \& Nehra, P. (2018). Determinants of Non-Performing Assets in Indian Banking Sector. The Management Accountant Journal, 53(7), 91-98.

Towpek, H., \& Borhan, J. T. (2006). Untung dalam sistem perbankan Islam. Islamic Banking and Finance Institute Malaysia (IBFIM).

Trujillo-Ponce, A. (2013). What determines the profitability of banks? Evidence from Spain. Accounting \& Finance, 53(2), 561-586.

Tulsian, M. (2014). Profitability analysis: A comparative study of SAIL \& TATA Steel. Journal of Economics and Finance (IOSR-JEF), 3(2), 19-22.

Uchendu, O.A. (1995). Monetary policy and the performance of commercial banking in Nigeria. Monograph, Research Department, CBN.

Vinh, N. T. H. (2017). The impact of non-performing loans on bank profitability and lending behavior: Evidence from Vietnam. Journal of Economic Development, (JED, Vol. 24 (3)), 27-44.

Wheelock, D., \& Wilson, P. (1995). Explaining bank failures: Deposit insurance, regulation, and efficiency. Review of Economics and Statistics, 77, 689-700.

\section{Appendix}

List of banks for research data

\begin{tabular}{lll}
\hline & Name & Code \\
\hline 1 & Asia Commercial Joint Stock Bank & ACB \\
2 & Joint Stock Commercial Bank for Investment and Development of Vietnam & BID \\
3 & Vietnam Export Import Commercial Joint Stock Bank & EIB \\
4 & Vietnam Joint Stock Commercial Bank for Industry and Trade & CTG \\
5 & Ho Chi Minh Development Commercial Joint Stock Bank & HDB \\
6 & Kien Long Commercial Joint Stock Bank & KLB \\
7 & National Joint Stock Commercial Bank & NVB \\
8 & Joint Stock Commercial Bank of Saigon - Hanoi & SHB \\
9 & Saigon Thuong Tin Commercial Joint Stock Bank & STB \\
10 & Joint Stock Commercial Bank for Foreign Trade of Vietnam & VCB \\
11 & Military Joint Stock Commercial Bank & MBB \\
12 & Vietnam International Joint Stock Commercial Bank & VIB \\
13 & Vietnam Prosperity Commercial Joint Stock Bank & VPB \\
14 & Petrolimex Commercial Joint Stock Bank & PGB \\
\hline
\end{tabular}




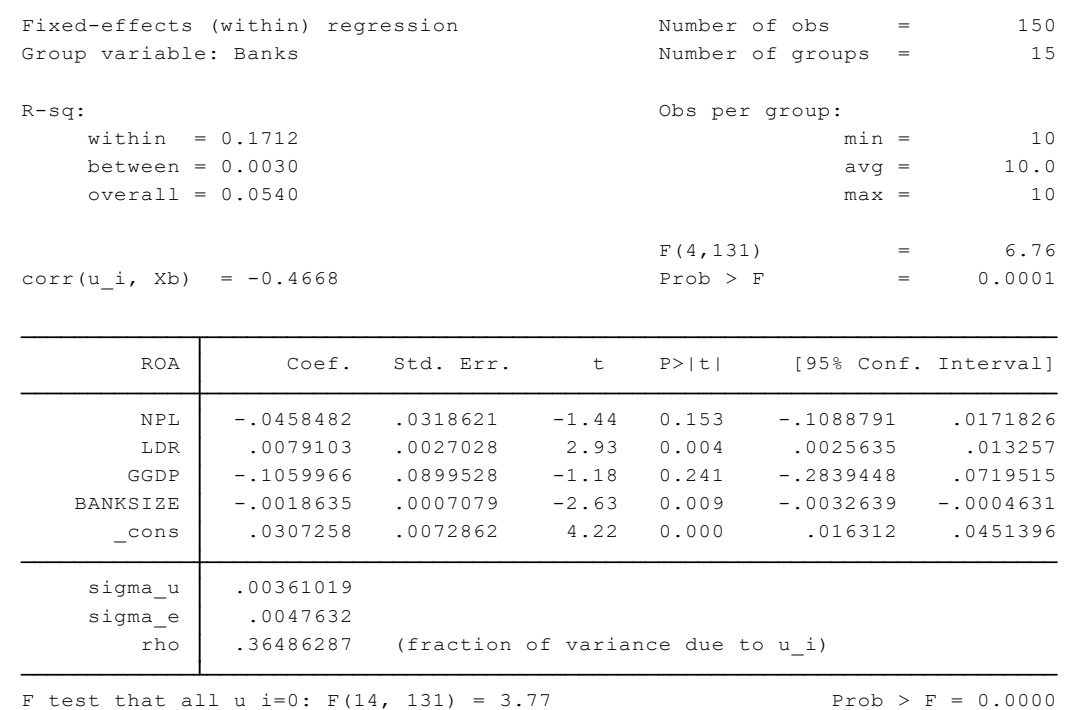

\section{Results from random effects model}

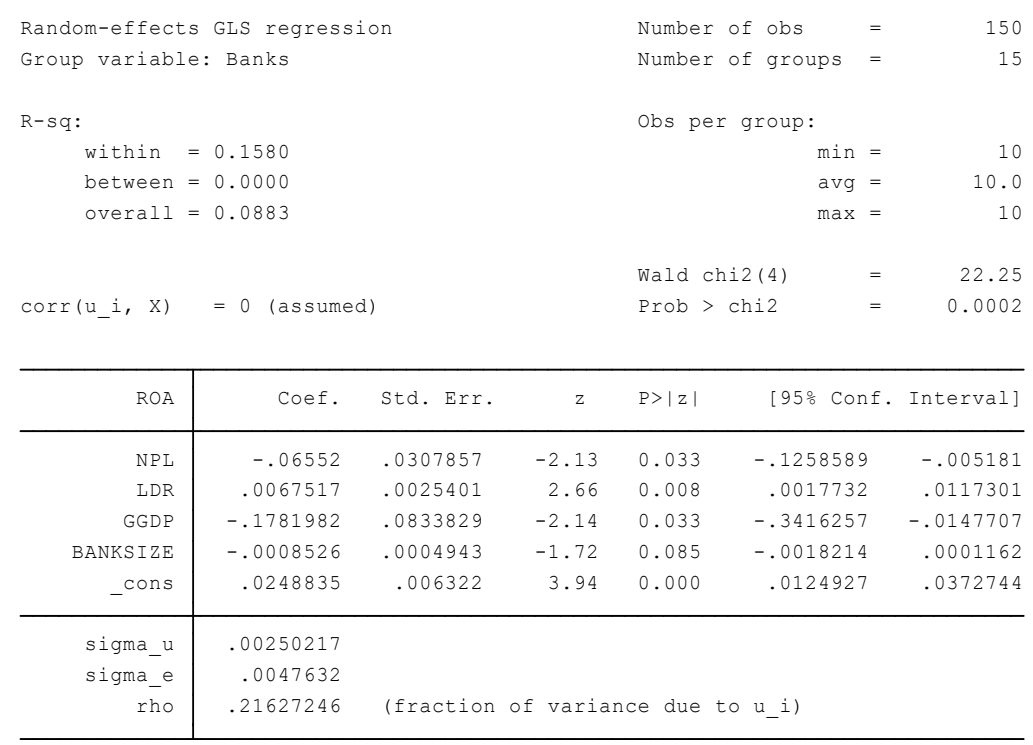

\section{Hausman test}

\begin{tabular}{|c|c|c|c|c|}
\hline & \multicolumn{2}{|c|}{ - Coefficients } & \multirow{3}{*}{$\begin{array}{c}(b-B) \\
\text { Difference }\end{array}$} & \multirow{3}{*}{$\begin{array}{c}\operatorname{sqrt}\left(\operatorname{diag}_{\left(V_{-}{ }^{b}-V_{-} B\right)}\right) \\
\text { S.E. }\end{array}$} \\
\hline & (b) & (B) & & \\
\hline & fe & re & & \\
\hline NPL & -.0458482 & -.06552 & .0196717 & .0082117 \\
\hline LDR & .0079103 & .0067517 & .0011586 & .0009236 \\
\hline GGDP & -.1059966 & -.1781982 & .0722016 & .0337461 \\
\hline BANKSIZE & -.0018635 & -.0008526 & -.0010109 & .0005068 \\
\hline
\end{tabular}

$\mathrm{b}=$ consistent under $\mathrm{Ho}$ and $\mathrm{Ha}$; obtained from xtreg

$\mathrm{B}=$ inconsistent under $\mathrm{Ha}$, efficient under Ho; obtained from xtreg

Test: Ho: difference in coefficients not systematic

$$
\begin{aligned}
& \operatorname{chi2}(4)=(b-B)^{\prime}\left[\left(V_{-} b-V_{-} B\right)^{\wedge}(-1)\right](b-B) \\
& 6.32 \\
& \text { Prob>chi2 }=0.1765
\end{aligned}
$$


Feasible General Least Square

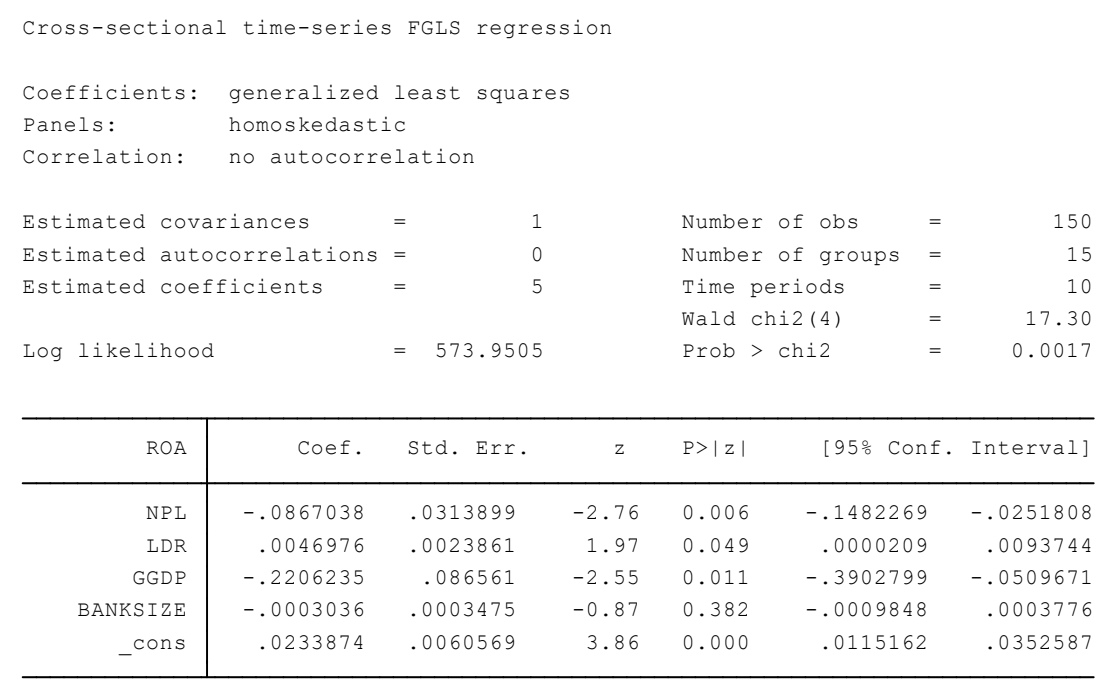

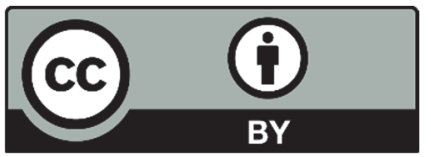

(C) 2020 by the authors; licensee Growing Science, Canada. This is an open access article distributed under the terms and conditions of the Creative Commons Attribution (CC-BY) license (http://creativecommons.org/licenses/by/4.0/). 